\title{
The generic structure of the Thai Prime Minister's weekly address
}

\author{
Narongdej Phanthaphoommee \\ Research Institute for Languages and Cultures of Asia, Mahidol University, 999 Phutthamonthon Sai 4 Rd., \\ Salaya, Phutthamonthon District, Nakhon Pathom 73170 Thailand
}

\begin{abstract}
This study examines how the weekly Thai prime ministerial address constitutes as a genre and explains its implications against the Thai socio-political backdrop. Drawing on data derived from Thaksin Shinawatra's, Abhisit Vejjajiva's, Yingluck Shinawatra's and Prayut Chan-ocha's weekly addresses, the study applies an integrated framework of genre analysis based on Systemic Functional Linguistic and Critical Discourse Analysis perspectives. The findings reveal that although the format of the Thai weekly address is emulated that of the US president's, this unidirectional, weekly televised communication differs from other world leader's addresses. Following an interpretation of the findings, the paper argues that the weekly address has become ritualised in Thai politics since almost all post-Thaksin prime ministers have employed this political marketing strategy to justify their rule and promote their administration's performance in such a way as to embody the 'senior-cum-leader' trait that has become a major Thai tenet. The generic structure of the show is loosely organised around a long-running time slot and imbued with a strong sense of positivity and glorification of the century-long concept of Thai nationalism.
\end{abstract}

Keywords: Generic structure; genre; prime minister; Thailand; weekly address

\begin{tabular}{|ccc||}
\hline $\begin{array}{c}\text { First Received: } \\
\text { 2 October 2020 }\end{array}$ & $\begin{array}{c}\text { Revised: } \\
\text { Final Proof Received: }\end{array}$ & $\begin{array}{c}\text { Accepted: } \\
\text { 29 March 2020 }\end{array}$ \\
21 May 2021 & Published: \\
\hline How to cite (in APA style): & 31 May 2021 \\
Phanthaphoommee, N. (2021). The generic structure of the Thai Prime Minister's weekly \\
$\begin{array}{c}\text { address. Indonesian Journal of Applied Linguistics, 11(1), 114-123. } \\
\text { https://doi.org/10.17509/ijal.v11i1.34662 }\end{array}$ \\
\hline
\end{tabular}

\section{INTRODUCTION}

Since its inception in Thailand, the radio broadcasting has long been exploited by the Thai leaders as a propaganda tool to promote their agenda and gain the political and commercial upper-hand. The origin of the radio address can be traced to the early 1940s when Field Marshal Phibulsongkram instilled his version of Thai nationalism and modernity through Radio Thailand. By the end of 1980s, despite rapid economic growth, advances in technology and increasing public participation in mass communication, radio and television remained a tool used by the state and military to bolster national security and shape public opinion (Hirunburana, 2009; Siriyuvasak, 1989; Setachandhana, 1994).

The actual 'weekly prime ministerial address' was initiated in 2001 by former Prime

*Corresponding Author

Email: narongdej.pha@mahidol.edu
Minister Thaksin Shinawatra. By emulating the format of Franklin D. Roosevelt's weekly fire-side chats (Vejjajiva, 2009), Thaksin changed the rules of the game in Thailand by directly appealing to Thailand's rural constituents. Thaksin's success in this prompted Surayud Chulanont to offer a weekly address via television and Samak Sundaravej used his public speaking skills in something akin to a talk show. Abhisit Vejjajiva used almost the same method, but in a more formal studio setting, and Yingluck Shinawatra, Thaksin's younger sister, followed similar suit but was far less opiniated and self-assured than her brother. Other than Somchai Wongsawat, whose premiership was short-live, all post-Thaksin prime ministers adopted this seemingly traditional PM approach to rhetoric and the use of media to garner the public's attention (Phanthaphoommee, 2019, p. 22). 
A week after the May 2014 coup, the thenarmy leader Prayut Chan-o-cha undertook his first weekly address. The rigid style and format of the address reflected Prayut's own personality and practice as a career soldier. The broadcast was compulsory for all TV channels every Friday evening. Dressed in uniform, Prayut appeared on screen standing on a podium and talked directly to the camera via teleprompter. English subtitles provided a novel feature, and the programme was considered by observers as an effort to "rebrand" and improve the image of Thailand's nascent but by no means first military government (Desatova, 2018). This seems to have global relevance because other state leaders use similar political strategies to gain popularity, as seen in the cases of Indian Prime Minister Narendra Modi hosting his monthly radio address (Parashar, 2021) and US President Joe Biden recently reviving the tradition of weekly address to directly talk to the people (Slotkin, 2021).

In Thailand, Thaksin's weekly address served as a platform for the enhancement of his administrative power and popularity, and justification of his business approach to the country's management (McCargo \& Pathmanand, 2005). In Prayut's case, the official objective of the programme was stated clearly in the oft-repeated slogan 'Return Happiness to the People'. The way in which key topics (such as the 12 Thai values, Pracharat Rak Samakee, Thailand 4.0) are presented can be seen as his endeavour to explain the status quo and justify government initiatives. The principal function of his addresses is not entirely different from that of Thaksin (Kanjanawisit, 2004). The way in which Prayut utilised the mass media to disseminate his achievements is clearly similar to what his predecessors did before him. This political rhetoric was exploited as a tactical diversion and expected to help relieve the feelings of insecurity concerning military rule and retain the legitimacy by creating a form of received public participation (McCargo, 2015). This study focuses on how the weekly address is shaped as a genre for political purposes and how it is presented to the Thai public.

There are a number of studies on the state leader's communication to the public, especially among political scientists. To begin with, Scacco (2011) studied weekly addresses by US presidents Clinton, Bush and Obama, finding that their addresses were aimed at shaping the weekend news and responding routinely to weekly events and functioned as a secular sermon, mediated log and a means for marking capital time. Similarly, Meernik and Ault (2013) investigated US presidents' weekly radio addresses (from 1993 to 2003) and found that they represented presidential agenda-setting by influencing the weekly agenda through the topics they highlighted in order to direct public attention towards certain issues or divert it away from others.
Studying the inaugural addresses of American presidents during the Cold War era, Kuosmanen (2015) found that by treating established allies and friends as supporters, presidential rhetoric seemingly tried to encourage people of oppressed nations to embrace American values. Later, Scacco and Coe (2016) studied how US presidential communication and proposed the notion of "ubiquitous presidency" by which modern presidents attempt to make themselves accessible, personal and pluralistic, thereby cultivating a highly visible and almost constant presence in the political and nonpolitical arenas. Recently, Coe and Griffin (2020) investigated Donald Trump's tweets as a form of political communication during his first two years in office and found that his invocation of a marginalised identity in his Tweeter account is clearly derogatory. All of these studies focused mainly on political function of the leader's communication. It is also worthwhile to explore the linguistic aspect of this political genre, which is one of this paper's key concerns.

In terms of genre analysis, there are quite a number of studies on genre in the Thai context, such as hotel brochures (Thumvichit \& Gampper, 2019), research article abstracts (Vathanalaoha \& Tangkiengsirisin, 2018), and comparisons of scientific research articles written in Thai and English (Kanoksilapatham, 2007). However, the weekly addresses as a political genre and their effects on politics have yet to be fully investigated. There are only few studies on individual prime minister's weekly shows, e.g. those of Samransook (2002), Kanjanawisit (2004), and Traijakvanich (2019). These studies paid little attention to the generic structure or textual features that distinguish the addresses from those of leaders of other countries. The present study therefore attempts to answer the following questions:

1. How does the weekly prime ministerial address constitute as a genre?

2. What is the nature of its generic structure and implications for the Thai society?

\section{SFL view of genre}

Drawing on Halliday's model of language, Martin and Rose (2007, p. 8) define genre as 'a staged, goal-oriented social process', while Thompson (2014, p. 42) considers it simply as 'register plus communicative purpose'. An individual normally participates in different genres in different groups of people, and uses different genres to achieve his/her purpose. According to Eggins, (2004, p. 78), a genre can be conditioned by sociocultural environment, which determines a pattern of register variables. Register means the variation of language use in certain contexts, characterised by three dimensions: Field, Tenor, and Mode. Different forms of genre can be realised for different subject matter (construing ideational meaning). The people 
involved in a genre may be close or distant, equal or unequal (enacting interpersonal meaning). The textual organisation is either written or spoken, depending on the situation and feedback (conveying textual meaning). The last element is the strands of meaning formed by language (lexis and syntax), which is expressed in the way one turns meanings into wordings and how the text producer exploits the meanings (Martin \& Rose, 2007, p. 297).

Eggins (2004) considered characteristics of a genre by explaining that one should look for the aspect of the meaning of a text that is related to the way in which the text resembles others of the same genre. This is 'the generic identity of a text' which comprises three dimensions.

(1) Register configuration - when situations recur, social members develop recurrent ways of using language to interact among themselves within those situations to the extent that those ways become stable or habitualised. A genre is formed when certain values for Field, Tenor and Mode regularly co-occur and become stabilised in the culture as a typical situation. This recurring pattern in language use related to this situation can be relatively predictable.

(2) Schematic structure - the linguistic expression of a text shows some signs of stages or step-by-step organisation. These stages are functional and occur in a particular sequence. A genre is primarily built up from constituent stages: beginning, middle and end. Each stage (form of different constituencies) has its own function; for instance, the beginning to introduce something, the middle to elaborate on it, and the end to sum it up.

(3) Realisational pattern - realisation refers to the way a meaning becomes encoded or expressed in a semiotic system. Different genres are realised through different use of language when we see only certain register variables in that genre. For example, in a horoscope we note certain words such as 'lifechanging' or 'love affair' to indicate its Field (romantic prediction), 'could be' or 'do not' to indicate its Tenor (giving advice/warning) and pattern of direct address to the reader as 'you' to indicate its Mode (cohesive structure).

\section{CDA view of genre}

According to Fairclough (2003), genres are one of the elements in the 'order of discourse', based on the Foucauldian concept of discourse. This 'order' is the social structuring of linguistic variation, which is constituted by social practices or the way to govern how the language is used to achieve certain things. The order of discourse comprises three elements.

(1) Genres are diverse ways of acting or of producing social life in the semiotic mode. Genres can be identified at different levels of abstraction. The term pre-genres refers to genres at the highest level: Narrative, Argument, Description and
Conversation. The lowest level is situated genres specific networks of social practices that occur in particular circumstances, such as ethnographic interview.

(2) Discourses are diverse representations of social life that are inherently positioned. Social actors who are positioned differently in society see and represent social life in different ways. The relationships between different representations reflect the relationships between different people because they are one part of the linguistic resources that people can deploy to gain cooperation or to separate one from another.

(3) Styles are the ways by which social actors reflect their identity and personality - how one speaks, writes, or moves. Styles are linked to process of how people identify themselves and are identified by others. One's style is constituted during one's life according to the discourses one encounters when socialising in a particular 'social role'. Characteristics of style are presented in various linguistic features: phonological features, vocabulary and metaphor.

Focusing on the analysis of an individual genre, Fairclough (2003, pp. 70-77) suggested identifying the following stages: Activity, Social relation and Communication technologies.

(1) Activity concerns social events with discoursal aspect. For instance, a lecture is regarded as a discourse-related social activity because it has its own organisational elements. It is common that a genre is a purposed-driven activity, but it is a matter of degree as to whether certain activities are more strategic or communicative. One needs to look for staging of a genre even though it might not be organised in a clear generic structure.

(2) Social relation refers to relations between social agents, which can be either between organisations, between individuals or between organisation and individual. The communication within social relations can be different based on two dimensions: social hierarchy and social distances, whereby the former relates to power and the latter to solidarity.

(3) Communication technologies are the way through which discourse is projected. There are four possible ways in analysis; namely, two-way nonmediated (such as face-to-face conversation), twoway mediated (such as telephone, email, video conference), one-way non-mediated (such as lecture), and one-way mediated (such as print, television, internet).

Eggins's and Fairclough's approaches to genre identification are similar. The concepts of activity, social relation and communication technologies link closely to the register variables of Field, Tenor and Mode. Table 1 summarises the similarities and differences between the two approaches. 
Table 1

A comparison of Fairclough's and Eggins's perspectives on genre analysis

\begin{tabular}{|c|c|c|c|}
\hline \multicolumn{2}{|c|}{ Fairclough's perspective } & \multicolumn{2}{|c|}{ Eggins's perspective } \\
\hline Individual genre analysis & Register variables & Generic identity of a text & Register variables \\
\hline $\begin{array}{l}\text { Activity } \\
\text { - Communicative/ strategic } \\
\text { - Generic structure } \\
\text { - Pre-genres }\end{array}$ & $\begin{array}{l}\text { Field } \\
\text { Mode } \\
\text { Mode }\end{array}$ & $\begin{array}{l}\text { Register configuration } \\
\text { - Habitualisation } \\
\text { - Recurrent configurations of } \\
\text { register variables }\end{array}$ & $\begin{array}{l}\text { Field/Tenor/Mode } \\
\text { Field/Tenor/Mode }\end{array}$ \\
\hline $\begin{array}{l}\text { Social relation } \\
\text { - Social hierarchy } \\
\text { - Social distance }\end{array}$ & $\begin{array}{l}\text { Tenor } \\
\text { Tenor }\end{array}$ & $\begin{array}{l}\text { Schematic structure } \\
\text { - Sequence } \\
\text { - Functional stages }\end{array}$ & $\begin{array}{l}\text { Mode } \\
\text { Mode }\end{array}$ \\
\hline $\begin{array}{l}\text { Communication technologies } \\
\text { - Four possibilities of } \\
\text { communication }\end{array}$ & Mode & $\begin{array}{l}\text { Realisational patterns } \\
\text { - Discourse-semantic, } \\
\text { lexicogrammatical, phonological } \\
\text { patterns }\end{array}$ & Field/Tenor/Mode \\
\hline
\end{tabular}

Activity is primarily concerned with the topics and purpose of a genre. It is similar to Field, which focuses on what the text is about and how the text producer's experience is presented. Social relation emphasises relations between individuals and organisations; likewise, Tenor concerns relations between participants, such as speaker and audience. Communication technologies involve four possible ways of communicative events owing to the advanced communication technologies. They are regarded as one of the elements of Mode or the form of communication.

\section{METHOD}

The present study uses the data of Thaksin's (20012006), Abhisit's (2008-2011), Yingluck's (20112014), and Prayut's addresses (2014-2016). All data are available in the public domain. There are a total of fifteen addresses that were purposively selected for this study. Thaksin's addresses (28 April 2001, 9 February 2002, 16 February 2002, 27 April 2002) are based on the book-length collection of his addresses (Secretariat of the Prime Minister, 2002). Abhisit's addresses (27 December 2009, 23 August 2009, 24 April 2010) and Yingluck's addresses (14 January 2012, 26 January 2013, 19 October 2013) were retrieved from YouTube and transcribed by the author. Prayut's addresses (1 August 2014, 5 September 2014, 6 December 2014, 25 July 2014, 26 August 2016) were retrieved from the Thai government website (thaigov.go.th). Other addresses were taken into consideration when relevant topics were discussed.

Eggins's and Fairclough's frameworks for genre analysis are combined and used to analyse the selected addresses. The paper starts by looking at recurrent register variables of texts studied (Eggins, 2004), or activity in Fairclough's term. It goes on analysing social relation found in the addresses (Fairclough, 2003) and their common schematic structure (Eggins, 2004).

With the above method, the present study tries to answer the question as to how a genre is realised with register variables and what characteristics a genre may have in the Thai sociocultural environment that conditions the use of language. Fairclough's concept can help emphasise the elements of a genre as the result of social interaction and discourse practices in the Thai political context. The study equally gives the importance to the textual (schematic structure, pre-genres) and contextual level (social relations and ways of communication).

To identify the pattern and ensure the recurrence of generic structure, the researcher read through the data under investigation multiple times and manually checked for relevant and similar structure and language use among the four prime ministers.

\section{RESULTS}

\section{Realisational pattern of register}

This part is largely based on Eggins's (2004) analysis of register variables in a genre. In all the PMs' weekly addresses being examined, their ideational meanings could be predicted from the various topics in the speeches (Field), realised through the use of lexical items related to government performance and policy implementations, such as economic development schemes in Abhisit's show on 23 August 2009, eradication of social problems in Prayut's address on 9 October 2015, and populist projects (One Tambon One Product and Pracharat Project). This political marketing constitutes as a genre due to the premiers' recurrent choice of lexical terms that indicated progress in these projects so as to appeal to their constituents and the Thai people as a whole. All the PMs, to a large extent, touched upon these themes.

Another predictable meaning is the interpersonal relationship created between the prime minister and his/her audience (Tenor), specifically the way the audience is patronized by the PM. This is shown in the following examples. Note that the English translations of Prayut's address were 
extracted from the official translation appeared on the Thai government website. The translations of other PM addresses are mine.

\section{Example 1}

Today, let's come together to work for the country. Don't criticise without suggestions. (Thaksin, 16 February 2002)

\section{Example 2}

Finding the answer to the political [deadlock] must not create a political norm ... a recourse to violence, threats that lead to [such] answer ... I think [you] must understand this. (Abhisit, 24 April 2010)

\section{Example 3}

Do not criticise so much, wait and see. (Prayut, 1 August 2014)

The imperatives 'let's', 'Don't' (Example 1) and 'Do not', 'wait and see' (Example 3) imbue the sense of obligation levied upon the audience by a higher authority of the speakers, such as their prime minister. Likewise, the use of the modal verb 'must' and the projection 'I think' (Example 2) asserts a proposition that restricts the degree of expression for alternative voices or other opinions (Martin \& Rose, 2007, pp. 49-52).

In all of the PMs' speeches the meanings of advice/warning are relatively obvious; the audience understands this through a recurrent pattern of mood and modality, such as ya or ham 'do not', karuna 'please', and tong 'must'. Due to a tradition of respecting seniority and their domineering attitude, PMs normally address the public using paternalistic terms. The selection of these kinds of mood and modality demonstrates the speaker's control and power. Yet, the degree to which modal intensity varies depends on the speaker's individual personality - Abhisit, with his gentleman-like manner, and Yingluck, who is soft-spoken, tended to rely less on imperatives and modals of obligation.

The textual organisation (Mode) of the address is evident in the way the speakers typically pepper their speeches with discourse markers (such as thang $n i$ 'anyhow', yang rai ko di 'however', dan setthakit 'on the economy') signifying the turn of topic and making the speech sound coherent. However, there are no other clearly defined signposts that index the whole address; it solely depends on each PM's wit and ability to ad-lib or deviate from topic at will that determine how coherently and successfully the information is delivered. This feature of changing topics is noteworthy in the cases of Thaksin and Prayut who are naturally talkative and strong-willed, with a commander-type personality (McCargo \& Pathmanand, 2005; Amornpat, 2015).

\section{Social relation}

This part is drawn upon Fairclough's (2003) concept of relations between social agents. The relationship between so-called ruling class (elite) and the public, as demonstrated in the weekly address, is manifestly based on social hierarchy through which the government exercises persuasive power or even direct authority over individuals with strict orders or harsh measures. Prayut's administration is particularly guilty of this through the enforcement of martial law and wanton use of the Section 44 powers granted under Interim Constitution of 2014. Criticised for being dictatorial, Section 44 gave full legal power to the military and subsequently the government aiming to "curb any acts that the government considers harmful to national peace and stability". Prayut's addresses serve as a platform for the government to promulgate and reinforce the need for such measures, as seen by the emphasis on national security and law violation, for example, in his address on 1 August 2014. Social distance in the weekly show is also noticeable. This PM's address is a form of unidirectional, political communication. The government operates at a national level, whereas individuals listen to the address or read the report in their specific locales except in Thaksin's case in which he attempted to better engage with his constituents by delivering his talk informally.

In their speeches, all the prime ministers frequently used the pronoun 'we' in both inclusive and exclusive senses; the first one signifying a unity of government and people, while the latter referring exclusively to the speaker and his/her administration. In our case, 'we-inclusive', representing speaker as government plus Thais in general, helps reduce the sense of hierarchy and distance by implying unity and a collective 'all of us'.

\section{Example 4}

Especially in Thailand, we rely much on agriculture. If we use water efficiently ... I believe that the agricultural products will be better. (Yingluck, 19 October 2013)

On the other hand, in referring to the government alone, the 'we-exclusive' purposively maintains the traditional hierarchy and distance.

\section{Example 5}

Thai society should learn from past lessons and have confidence in $\underline{u s}$... in the government. We will genuinely try to fix these problems and the past errors. (Prayut, 26 August 2016)

The choices of pronoun in Example 4 and Example 5 are associated with interpersonal meaning. The first-person plural rao 'we-inclusive', including the speaker, is typically used by PMs to refer to the people in general in order to provide a sense of Thai nationalism, while rao 'we-exclusive' refers to the cabinet. According to Wales (1996), in political texts the use of 'we-inclusive' and 'weexclusive' is interchangeable and is applied as such in the present case. This phenomenon is comparable to Obama's inaugural speech, in which both senses 
of 'we' were used to a varying degrees to appeal to his audience (Munday, 2012).

When addressing their audience, all PMs choose to use the second-pronoun than 'honorific you', which reflects the political tradition of honouring an inferior to gain their trust, and ultimately their vote (Phanthaphoommee, 2019). Interestingly, this second-person pronoun is barely heard in Thaksin's speeches; he tended to focus his talks on explaining the progress of policy implementation and referred to the audience with a neutral manner or, otherwise, entirely omitted the pronouns. In contrast, this type of pronoun is frequently used in Prayut's speeches; particularly when he elaborates on problems arising from a lack of understanding of the country's management and opposition to the coup and his tenure. He uses the pronoun than to refer to those who are in no position to solve the country's problems and to stress the point that it is incumbent on his government to alleviate their plight, as in Example 6.

\section{Example 6}

If you are scattered and on your own it will be more difficult to manage [to get access to assistance and funds]. (Prayut, 5 September 2014)

The pronoun than is also used to address to his opponents who always protest against the government's initiatives, as in Example 7.

\section{Example 7}

[Your] condemning us while we are trying to improve the situation is not entirely fair. I ask for just consideration. (Prayut, 25 July 2014)

The official translation of Example 7 is interesting because the pronoun is entirely dropped and replaced with the nominalisation 'condemning' to conceal who he is referring to or those who are doing the condemning.

The PM's idiosyncratic use of language differs according to the personality traits of each. For instance, Thaksin always used informal words with a causal tone of speech (Prasithrathsint, 2004), while Prayut preferred to repeat himself or elaborated on the same points for several minutes (McCargo, 2015). This means they have different ways of appealing to the public, leading to different degrees of engagement with them. Although an analysis of the PM's idiosyncratic language use would help identify individual patterns of speech (Phanthaphoommee, 2019), the scope of this current paper does not extend to this area of study.

Another interesting aspect of social relationships includes changes to the format of $\mathrm{TV}$ interviews whereby TV hosts act as a third party to the communication, thus modifying the audience's role as direct addressees to one of mere viewers. In dialogue, several conditions such as turn taking, the selecting of topics or summarising what has been said are the key roles of power-controlling in conversation (Fairclough, 2003, p. 78). After media criticism of his "one-man-show" format and unpopular talking-down style, Prayut's show was changed to become an interview with the premier, beginning from 15 April 2016 up to 3 June 2016. However, without apparent reason, the format was reverted to the previous narrative and descriptive structure with his talk delivered from a podium.

Dialogue is primarily the featured generic structure of Yingluck's and Abhisit's addresses, and Abhisit even hired celebrity host Ketsepswat Palagawongse na Ayutthaya to conduct his interview on 23 August 2009 in an attempt to attract a wider audience. Yingluck preferred not to talk or be interviewed alone, and on numerous occasions invited members of her cabinet to explain difficult issues on her behalf. For example, the then Transport Minister Chadchart Sittipunt was invited to elaborate on railway mega-projects on 26 January 2013. The same method was in fact used for some of Prayut's addresses in which he invited his deputy prime ministers to discuss projects related to their ministry. For example, on 1 May 2015, a group of ministers appeared on the show, explaining their policy implementation pertaining to senior citizens, educational reform and technologies for agriculture.

\section{Schematic structure}

This part is based on a mixture of Eggins's (2004) schematic structure and Fairclough's (2003) pregenres. The findings reveal that the PM's weekly address has a loosely devised schematic structure, with no specific step-by-step structure of a genre. Each programme usually lasts more than ten minutes (as in Abhisit's case) to an hour and a half (in Thaksin's and Prayut's). According to Eggins (2004, p. 60), each genre stage carries with it a meaningful function. In our present case, the opening section normally incorporates the most important topics, occupying nearly one-third of the show-time. In always presenting activities related to the royal family, Prayut's and Abhisit's programmes provided an aura of royal prestige.

\section{Example 8}

Last week I was in Chiang Mai on Saturday and Sunday. I was attending the Chiang Mai Flower Festival and went to visit the Doi Tung Development Project by Somdet Ya. (Thaksin, 9 February 2002)

Affectionately called by most Thais, Somdet $\mathrm{Ya}$ 'the royal Grandmother' refers to the late King Bhumibol's mother and was regularly mentioned at the beginning of Thaksin's show. Also, such monarchy-related events are typically selected as an introduction to Prayut's talk. This implies that he was attempting to glorify the royal causes and expect that by beginning their speech in this manner, his administrations would be blessed.

\section{Example 9}

On 30 August 2014, His Majesty the King [Rama IX] graciously granted a royal command appointing the Council of Ministers or Cabinet. It is an immense honour for all of its members. (Prayut, 5 September 2014) 
At the beginning of all PM talks, royal and Buddhist-related subjects are always mentioned, thereby reinforcing the image of PM as an ideal leader who was pious and loyal to the royal and religious institutions (Sattayanurak, 2005, p. 24-25). This is most evident in Abhisit's and Prayut's addresses. However, on many occasions in Thaksin and Yingluck conveyed news of their traveling cabinet meetings in different provinces as a precedent to other royal and religious topics. The structure of Yingluck's addresses relied heavily on turn taking with the TV show's host. Not being especially eloquent and often mispronouncing crucial terms meant that the hosts were usually required to lead the discussion on her behalf, so the sequence and structure of the interview needed to be well prepared and scripted. Furthermore, at times the script failed to lead with royal news, as with Yingluck's addresses on 5 May 2012, 26 January 2013 and 19 October 2013.

The main part of the PMs' talks typically centred on topics related to policy initiatives or ongoing projects (see previous section). To hype their achievements, almost all premiers frequently talk about budgets and how their government uses them wisely, purveying the message of responsible financial and industrial facilitator, boosting the country's economy and infrastructure investment. These topic selections clearly demonstrate their perspectives and attitudes, as shown by the underlined phrases in Examples 10, 11 and 12.

Example 10

I had a chance to meet with the president of the Thai Bankers Association ... I mentioned the financial institutions system, I am worried about the problems it has. The government will do everything it can to strengthen all parties. (Thaksin, 9 February 2002)

\section{Example 11}

What [I] view [here] is a better quality of life. First things are roads [and] railways that would better the quality of life, leaving more time for family, [and] not being stuck in traffic jam. (Yingluck, 26 January 2013)

\section{Example 12}

One of the significant obstacles for conducting business is the bureaucratic sluggishness and timewasting. I have requested every state agency to find ways to shorten the bureaucratic process and provide an integrated One Stop Service. (Prayut, 5 September 2014)

In the above examples, although all three premiers had a similar take on selecting economic issues as one of the main themes to show how hardworking they were in managing the country, the degree of emphasis on each topic was rather different. Prayut stresses more on social problems and political reform as is typical of governments, especially during the first year of his premiership (Government Public Relation Department, 2015).
Focusing on Prayut's narrative, one can see the way he textualises his speech is to describe his activities in the previous weeks and how much benefits these efforts would be for Thai society. The narrative is not chronologically linked, and therefore the audience is forced to follow carefully his often disconnected vignette and the subjects he opts to raise. His points are arranged according to prepared notes. For instance, in the address on 5 September 2014 he began his show by mentioning the performance of the National Council for Peace and Order (NCPO) in regard to the late King Rama IX, and he continued by discussing national administration, state welfare, narcotics and transparency in public expenditure, respectively. This account of his activities was designed to support the general premise that his taking control of the country was timely and justified, at times using as one-sided argumentation to rail against the opposition, i.e., chastising the anti-coup protesters in his address on 6 December 2014.

According to Fairclough (2003, p. 81), argument as one of pre-genres comprises three moves: the Grounds being the premises of the argument, the Warrant justifying the inference from the Grounds to the third move, or the Claim. In Prayut's case, one can infer from his speeches, especially during the first two years of his premiership, that he generally tries to put forward the notion that political reform and reconciliation should come before a general election (Grounds); Thailand would be rid of the democracy 'problem' if Thais adhered to Thai-style democracy and suitable mechanisms to beget a better electoral process led by his government (Warrant); then the ultimate change towards a better political system for the country as a whole would be achieved (Claim). This 'loosely' argumentative structure of nearly every address can be interpreted as Prayut's ideological assumption.

The final part of the premiers' addresses always anticipated a promising future based on their policies, with the occasioned repeat mention of the royals as an expression of loyalty as in Thaksin's case (Example 13), or a review of his appeal to the audience as in Prayut's (Example 14).

\section{Example 13}

12 February is Chinese New Year, during which Her Royal Highness Princess Sirindhorn will graciously proceed to Yawarat. I will go [there] and have an audience with Her Royal Highness. (Thaksin, 9 February 2002)

\section{Example 14}

I assure you that all Cabinet Ministers will give full cooperation with each other. Everyone understands that we need to act swiftly, effectively and transparently with consideration given to all segments of society. Please do not be worried. (Prayut, 5 September 2014) 


\section{DISCUSSION}

All the examples in the previous section illustrate how similar the structures of the premiers' addresses are. However, although the format of the Thai weekly addresses was emulated that of the US President, its characteristics are unique. They have a strategic purpose that is akin to political marketing with a loose narrative structure (as shown in Examples 8 - 14) and similar pattern of lexicogrammar mainly revolving around politics and social problems, sometimes to the point of becoming repetitive in Prayut's case (Phanthaphoommee, 2019). However, when analysing this political genre, one has to bear in mind that individual PM's idiosyncrasies are sometimes considered an attribute and thus reflected in their speeches (as shown in Examples 1 - 3). This relates to the concept of 'styles', one of the elements in Fairclough's 'order of discourse', but this aspect is beyond the scope of this research.

To answer the first research question, the researcher discusses how the PM's weekly address constitutes as a genre by using the CDA and SFL integrated framework for genre analysis. In terms of CDA, there is a mixture of pre-genres in the weekly addresses: narrative/description, argument and dialogue. The social relations between the speaker and audience are both hierarchical and distancing; the extent of variation in both dimensions depends on the individual PM (as shown in Examples 4 - 7). The channel of communication is one-way with audio-visual support. In terms of SFL, the analysis of register variables helps us to understand that the audiences can recognise the weekly address as a genre by familiarising themselves with the recurrent pattern of wordings (lexicogrammar) and meanings (discourse semantics) pertaining to current political situations, various government policies and onesided argumentation against their political opponents (Samransook, 2002). This paper argues that this Thai-style political genre becomes ritualised (in Eggins's term) when almost all premiers adopt this kind of rhetoric, either after winning a general election (Thaksin in 2001, Abhisit in 2009, Yingluck in 2011) or seizing power by force (Surayud in 2007 and Prayut in 2014).

To answer the second research question on the nature of its generic structure, the researcher found that what makes the weekly address of Thai PMs unique and different from those of other country leaders is its loose structure in a long-running time slot. The structure of the address is considered 'loose' because it lacks precise step-by-step pattern, compared to the case of US presidents' addresses (Supan \& Snodin, 2012). As for its implications for the Thai socio-political environment, the researcher found that one of the weekly address' distinguishing features is the exaltation of patriotic conservatism to justify their rule after taking power, legally or illegally. Despite varying degrees of emphasis on topics, this loose-structured political marketing, to some extent, epitomises Embree's concept of Thai society in his classic essay. Embree (1950, p. 185) made a general observation from his working experiences in Southeast Asia and found that Thailand has a loose social structure system with a close social structure, whereby people conform closely to the formal social patterns of human relations. Moreover, the way phu-yai or a senior/influential person talks to the younger in a patronising fashion is one of the Thai social traits; it influences and to a certain extent dominates how the premiers address their audience. As evidences of the degree to which the modality of obligation oozes from the utterances illustrate (particularly in Thaksin's and Prayut's cases), the PMs' rhetoric by all means embodies one of the fundamental Thai tenets whereby the 'seniority-cum-leader' is the righteous and reasonable one who deserves full respect and obedience, mirroring the strict social hierarchy and distance. Often in real life, it even turns out to be a travesty of justice or a mercy in disguise to exploit such a deeply ingrained relationship or take advantage of such seemingly valuable advice offered by the idealistic leader. Owing to the century-long, dominant concept of nationalism being placed at the core of Thai society (Connors, 2007), the show schematism in question is typically replete with positive platitudes reflected in terms that rhapsodise over Thailand's glorious past and the 'Thailand-is-good' notion (Sattayanurak, 2005). This successfully justifies Prayut's show where he solicits attention by virtue of his personality as former commander-in-chief. This is in contrast to other world leaders' addresses, in which such Thai unique characteristics are not present (Kuosmanen, 2015; Dada et al., 2021).

However, although Yingluck's and Abhisit's weekly address are primarily presented as talk show with hosts, deviating from Thaksin's and Prayut's usual one-man-show format, Abhisit himself still heavily relies on the aura of traditional conservative figures (such as the Supreme Patriarch) to bless his cabinet. This can be observed in the main themes of his show in the later period of his premiership which were dedicated to countering criticisms of the harsh measures and crack-down taken by his government against anti-government protesters during the 2009 political crisis (Tundulyasaree, 2013, p. 85).

\section{CONCLUSIONS}

This study has explained how the weekly Thai prime ministerial address constitutes as a Thai-style genre with features that include a loose structure and focus on nationalism. This differs from the weekly addresses of other world leaders'. The linguistic evidence seen by the use of modals and pronouns clearly shows that Thai socio-political traditions have had a significant impact on these weekly 
shows. The selection of specific topics is fed by a political obsession with Thai conservative patriotism, particularly in the case of Prayut and Abhisit, and the propagandising of government initiatives and perceived successes as a feature of the content is obviously a strategy designed to garner the maximum political benefit possible from the time allocated for the addresses.

Its loose structure can possibly be inferred from the inconsistent use of signposts together with a mixture of repetition and the fact that the longrunning time slot is likely to make it difficult to organise a well-structured address. However, the projection of a positive attitude congratulating a century-long Thai nationalism and their cabinets' outstanding performance may or may not strengthen understanding and support through this televised propaganda, for such success largely depends on the individual PM's personality to persuade the public. Lastly, this analysis of Thai PMs' weekly addresses hopes to shed new light on Thailand's politics and be helpful in interpreting subtle meanings hidden in other political texts or utterances.

\section{ACKNOWLEDGEMENT}

The author would like to thank the Research Institute for Languages and Cultures of Asia (RILCA), Mahidol University for giving full support in research environment for this publication.

\section{REFERENCES}

Amornpat, C. R. (2015, September 15). The peril of Prayuth. New Mandala.

https://www.newmandala.org/the-perils-ofprayuth

Coe, K., \& Griffin, R. A. (2020). Marginalized identity invocation online: The case of President Donald Trump on Twitter. Social Media + Society, 6(1). 1-12. https://doi.org/10.1177/2056305120913979

Connors, M. K. (2007). Democracy and national identity in Thailand. NIAS Press.

Dada, S., Ashworth, H. C., Bewa, M. J., \& Dhatt, R. (2021). Words matter: Political and gender analysis of speeches made by heads of government during the COVID-19 pandemic. BMJ global health, 6(1), e003910. https://doi.org/10.1136/bmjgh-2020-003910

Desatova, P. (2018). Thailand 4.0 and the internal focus of nation branding. Asian Studies Review, 42(4), 682-700. https://doi.org/10.1080/10357823.2018.151255 5

Eggins, S. (2004) An introduction to systemic functional linguistics (2nd ed.). Continuum.

Embree, J. F. (1950). Thailand-A loosely structured social system. American Anthropologist, 52(2),
181-193.

https://doi.org/10.1525/aa.1950.52.2.02a00030

Fairclough, N. (2003). Analysing discourse: Textual analysis for social research. Routledge.

Government Public Relation Department. (2015). The announcement of Government's one-year performance. Government Public Relation Department.

http://hq.prd.go.th/foreignPRD/ewt_dl_link.ph p?nid=409

Hirunburana, T. (2009). Botbat wittayu krachaisiang pheua kham-mankhong haeng chat [The role of radio broadcasting for nation integration] [Unpublished master's thesis]. Thammasat University Thailand.

Kanjanawisit, Y. (2004). Krabuankansangkhwammai lae botbatwatakam "raikan nayok thaksin kui kap prachachon" [The process of meaning construction and the roles of discourse in "Premier Thaksin talks with the people program"] [Unpublished master's thesis]. Chulalongkorn University.

Kanoksilapatham, B. (2007). Writing scientific research articles in Thai and English: Similarities and differences. Silpakorn University International Journal, 7, 172-203. https://www.thaiscience.info/Journals/Article/S UIJ/10499122.pdf

Kuosmanen, S. (2015). "With friends and former foes": The functional roles of international collaborative partners and their relationships with the United States in inaugural addresses of AmRFdakPFeNGdis since 1949. SKY Journal of Linguistics, 28, 225-248. http://www.linguistics.fi/julkaisut/SKY2015/S KYJoL28_2015.pdf

Meernik, J., \& Ault, M. (2013). The tactics of foreign policy agenda-setting: Issue choice and the president's weekly radio address. International Area Studies Review, 16(1), 7488. https://doi.org/10.1177/2233865913478247

McCargo, D. (2015). Thailand in 2014: The trouble with magic swords. In D. Singh (Ed.), Southeast Asian Affaires 2015 (pp. 335-358). Institute of Southeast Asian Studies. https://doi.org/10.1355/9789814620598-022

McCargo, D., \& Pathmanand, U. (2005). The thaksinization of Thailand. NIAS.

Martin, J. R., \& Rose, D. (2007). Working with discourse: Meaning beyond the clause. Continuum.

Munday, J. (2012). Evaluation in translation: Critical points of translator decision-making. Routledge.

Parashar, S. (2021, March 28). PM Narendra Modi to address nation through his monthly radio programme 'Mann Ki Baat' today. Zee News. https://zeenews.india.com/india/pm-narendramodi-to-address-nation-through-his-monthly- 
radio-programme-mann-ki-baat-today2351094.html

Phanthaphoommee, N. (2019). The ideology and translation of the Thai prime minister's weekly addresses (2014-2016) [Unpublished doctoral dissertation]. University of Leeds.

Prasithrathsint, A. (2004). Watchanaleela thaksin watasin kin chai prachachon [Thaksin's speech style: rhetoric that captures the people's heart]. In A. Prasithrathsint (Ed.), Ruthan phasa ruthan kan-mueng [Aware of language, aware of politics] (pp. 149-198). Ko Kid Duay Kon.

Samransook, R. (2002). Watakamwikro raykan nakok thaksin kui kap prachachon lae chuan online [Discourse analysis of 'Premier Thaksin talks with the people' and 'Chuan online' programs[ [Unpublished master's thesis]. Chulalongkorn University.

Sattayanurak, S. (2005). The construction of mainstream thought on "Thainess" and the "truth" constructed by "Thainess". Same Sky Books, 3(4), 68-81.

Scacco, J. M. (2011). A weekend routine: The functions of the weekly presidential address from Bill Clinton to Barack Obama. Electronic Media \& Politics, 1(4), 66-88. https://scholarcommons.usf.edu/spe_facpub/93 0

Scacco, J. M., \& Coe, K. (2016). The ubiquitous presidency: Toward a new paradigm for studying presidential communication. International Journal of Communication, 10, 2014-2037.

https://ijoc.org/index.php/ijoc/article/view/451 $6 / 1635$

Secretariat of the Prime Minister. (2002). Nayok thaksin khuy kab prachachon (28 mesayon 2544-27 mesayon 2545) [Premier talks with people (28 April 2001 - 27 April 2002)]. Public Relations Department.

Setachandhana, S. (1994). Kan pheuyphrae prachathipatai khong raikan sonthana thang witthayu rawang naiman chuchat kap naikhong rakthai chaung phoso 2484-2486 [The dissemination of democracy through radio program of Nai Man-Nai Kong's conversation in 1941-1943] [Unpublished master's thesis]. Chulalongkorn University.
Siriyuvasak, U. (1989). Radio in a transitional society: The case of modern Thailand [Unpublished doctoral dissertation]. University of Leicester.

Slotkin, J. (2021, 6 February). Biden revives presidential tradition, releasing first weekly address. National Public Radio. https://www.npr.org/2021/02/06/964889898/bi den-revives-presidential-tradition-releasingfirst-weekly-address

Supan, K. \& Snodin, N. S. (2012). A comparative study of genre analysis in inaugural addresses delivered by Barack Obama and George Washington. Manutsayasat Wichakan, 19(2), 145-165. https://so04.tcithaijo.org/index.php/abc/article/download/541 23/44923

Thompson, G. (2014). Introducing functional grammar (3rd ed.). Routledge.

Thumvichit, A., \& Gampper, C. (2019). Composing responses to negative hotel reviews: A genre analysis. Cogent Arts \& Humanities, 6(1), 1629154 https://doi.org/10.1080/23311983.2019.162915 4

Traijakvanich, N. (2019). Thai Prime Minister's weekly televised addresses in ideological and pentadic criticism [Unpublished master's thesis]. NIDA University.

Tundulyasaree, P. (2013) Reading Abhisit: Analysis of Abhisit Vejjajiva's television remarks during the united front for democracy against dictatorship's 'final' mass rally in Bangkok (March-May 2010) [Unpublished master's thesis]. University of Oslo.

Vathanalaoha, K., \& Tangkiengsirisin, S. (2018). Genre analysis of experiment-based dental research article abstracts: Thai and international journals. 3L: Language, Linguistics, Literature, 24(3), 1-14. http://doi.org/10.17576/3L-2018-2403-01

Vejjajiva, S. (2009, January 30). Abhisit not in tune with Sunday address. Bangkok Post.

Wales, K. (1996). Personal pronouns in present-day English. Cambridge University Press. 